\title{
Сравнительный анализ ансамбля транспозонов некоторых геномов
}

Мутовина О.А.

ИФБиБТ, 3 курс, Сибирский Федеральный Университет, кафедра биофизики, Красноярск, Россия

Ключевые слова: порядок, филогения, эволюция, покрытосеменные, голосеменные

Транспозонами называют участки генетической последовательности, способные самостоятельно перемещаться и размножаться внутри генома. К настоящему времени транспозоны обнаружены в геномах практически всех организмов, самого разного таксономического положения. Эти элементы генома являются весьма высоко частотными: они встречаются в большом числе копий, и само разнообразие транспозонов тоже велико. Однако обнаружение и изучение транспозонов в геномах хлоропластов растений проведено еще недостаточно. Более того, многие авторы утверждают отсутствие транспозонов в этих генетических системах.

Было проанализировано 100 геномов хлоропластов наземных растений из следующих семейств: Злаки, Бобовые, Кленовые, Жимолостные, Мальвовые, Мориновые, Маслиновые, Амарантовые, Астровые, Барбарисовые, Лютиковые, Пасленовые, Хризобалановые, Никтагиновые, Сосновые и Кипарисовые.

Основной задачей исследования был поиск и анализ транспозонов в этих геномах. Анализируемые геномы были взяты из базы NCBI. Поиск транспозонов осуществлялся программой Censor. B исследованных геномах хлоропластов наземных растений были обнаружены транспозоны. При этом поиск транспозонов осуществлялся по образцу: для поиска последовательности транспозона используется библиотека Repbase. Условиями поиска является выбор источника последовательности и активация опции поиска идентичных или почти идентичных фрагментов. Установлено, что в проанализированных геномах содержатся 4 различных транспозона; число копий отдельных транспозонов варьировало от 1 до 200.

Проанализирован состав транспозонов, встречающихся в различных геномах, по их структуре и близости друг к другу. 